\title{
Self-incompatibility and Self-fruitfulness in Pear cv. Agua de Aranjuez
}

\author{
Javier Sanzol ${ }^{1}$ \\ Unidad de Fruticultura, Centro de Investigación y Tecnología Agroalimentaria (CITA), Avenida de \\ Montañana, 930, 50059 Zaragoza, Spain \\ Maria Herrero
Departamento de Pomología, EE, De Aula Dei-CSIC, Campus de Aula Dei, 50080 Zaragoza, Spain
}

AdDitional Index words. Pyrus communis, self-fertility, parthenocarpy, fruit set, fruit drop, pollen tube growth

Abstract. Most pear (Pyrus communis L.) cultivars are impaired to set fruit under self-pollination, because selffertilization is prevented by a gametophytic self-incompatibility system. However, accumulated information in this species shows that often for a same cultivar, after self-pollination, a variable response in fruit set can be obtained in different years or growing conditions. In this work, we characterize self-incompatibility and self-fruitfulness in 'Agua de Aranjuez', the main Spanish pear cultivar, which also shows a variable response to self-pollination. Two years with a different fruit setting response after self-pollination, one with no fruit set and the other with a moderate fruit set, were compared for parthenocarpic fruit development and for pollen tube performance. Results show that in both years, this cultivar behaves as self-incompatible with absence of parthenocarpy. In selfed flowers, most pollen tubes are arrested in the upper half of the style, although in a small proportion of the styles, a pollen tube can reach the base of the style and eventually effect fertilization. Self-fertilization, although occurring at a low level, can explain the fruit set levels obtained under self-pollination given that flowers with just one fertilized ovule are able to set fruit. This behavior could explain confusing results about self-fruitfulness in 'Agua de Aranjuez' and other pear cultivars.

Self-fruitfulness, defined as the capacity of a cultivar to set fruit under self-pollination, has long attracted the interest of pear researchers and growers, because it determines to what extent pollination can be a limiting factor for an adequate cropping (Waite, 1894). Self-fertilization in pear is prevented by a gametophytic self-incompatibility system (de Nettancourt, 2001) and pear cultivars are generally considered self-incompatible (Crane and Lewis, 1942; Sanzol and Herrero, 2002; Stern et al., 2004; Tassinari et al., 2001). However, although in most fruit tree species such as those belonging to the genus Prunus L. self-fruitfulness and self-incompatibility are interchangeable concepts, the situation in pear seems to be more complex. Thus, some pear cultivars show parthenocarpic fruit set, which means that fertilization is not always a requirement for an economic cropping (Christine et al., 1956; Griggs and Iwakiri, 1954; Moriya et al., 2005; Nyeki et al., 1998). Moreover, the expression of the self-incompatibility (SI) reaction in Pyrus L. has been shown to vary depending on the cultivar or the experiment (Crane and Lewis, 1942; Ishimizu et al., 1999; Tassinari et al., 2004; Zhang and Hiratsuka, 2000). As a consequence, selfing and hence fruit set under selfpollination in this genus shows substantial levels of variation. Similar observations have been also reported for some apple (Malus $\times$ domestica Borkh.) cultivars (Schneider et al., 2001; Williams and Maier, 1977). Interestingly, both Pyrus and Malus L. belong to the subfamily Maloideae in the Rosaceae.

Received for publication 2 June 2006. Accepted for publication 24 Jan. 2007. We thank J.I. Hormaza and A. Wünsch for critically reading the manuscript. J.S. was supported by a predoctoral INIA fellowship and a postdoctoral contract INIA-CCAA. Financial support for this work was provided by INIA (Project grant RTA01-103), CICYT (Project grant AGL 2003-05318-C02-01), and

"Grupo de Investigación Consolidado" DGA A02, A-43.

${ }^{1}$ Corresponding author. E-mail: jsanzol@aragon.es.
In the Rosaceae family, SI is controlled by a single locus (S-locus) and at least two genes codified at this locus control the pollen and the pistil function of the recognition reaction in an allele-specific manner. So far, a stylar ribonuclease protein known as S-RNase (Broothaerts et al., 1995) and a pollen S-haplotype-specific F-box gene (Ushijima et al., 2003) have been proposed as the determinants of the female and male function, respectively. Pear S-RNase genomic (Zuccherelli et al., 2002) and cDNA (Takasaki et al., 2006) sequences have been already characterized. In the future, research at a molecular level will provide a solid basis to understand the causes behind the heterogeneity in the SI reaction in pear. Thus, in japanese pear (Pyrus pyrifolia L.), attempts have been already made to explore a relationship between the expression of the SI response and the amount of S-RNase protein in the style of different cultivars (Hiratsuka and Zhang, 2002).

Cultivar variability in the response to self-pollen in Pyrus was already reported in 1942 by Crane and Lewis. This observation has been later supported by different experiments either "in planta" (Ishimizu et al., 1999; Tassinari et al., 2004; Zhang and Hiratsuka, 2000) or monitoring pollen tube growth using a stylar culture technique (Hiratsuka and Zhang, 2002; Zhang and Hiratsuka, 2005). In pear, this variation in the SI response has jeopardized the classification of cultivars in relation to self-fruitfulness or self-incompatibility and it has often resulted in contradictory reports for the same cultivar (Callan and Lombard, 1978; Griggs and Iwakiri, 1954; Vasilakakis and Porlingis, 1985). Thus, 'Bartlett' pear has been classified as SI, self-sterile, self-fertile, or self-fruitful and, within these categories, in different degrees depending on the report (reviewed by Griggs and Iwakiri, 1954). Similarly, 'Comice' pear, although originally characterized as SI (Jaumien, 1968; Marcucci and Visser, 1987), has been reported to be able to crop properly without the need for a pollinizer 
(Callan and Lombard, 1978). Another example is 'Tsakoniki' pear, a Greek cultivar. After fruit set experiments after selfpollination, it was characterized as self-fruitful, whereas the observation of the pollen tube performance in selfed styles showed that it behaved as SI (Vasilakakis and Porlingis, 1985). A clear explanation is not yet available for these apparently conflicting results.

'Agua de Aranjuez' pear, the main Spanish cultivar, shows an erratic bearing and inconsistent reports about its selffruitfulness have also accumulated over the years. Initial studies indicated that a better fruit set could be obtained after crosspollination than self-pollination (Cambra, 1962). However, Sotes (1975) reported this cultivar to be self-fertile and stated that it was possible to get an economic crop without the provision of pollinizers. In a previous study analyzing self and cross-(in) compatibility relationships in a group of pear cultivars through the evaluation of pollen tube behavior in controlled pollinations (Sanzol, 2001; Sanzol and Herrero, 2002), we unambiguously characterized 'Agua de Aranjuez' as SI. However, a different fruit set response to self-pollination was also recorded for this cultivar along different years. In this work, we analyze the relationship between SI and self-fruitfulness in 'Agua de Aranjuez' pear by a combined analysis of fruit and seed set and pollen tube growth examination. The implications of the results on self-fruitfulness in pear are discussed.

\section{Materials and Methods}

Plant material. Twenty-year-old trees of 'Agua de Aranjuez' pear (also known as 'Blanquilla'), grafted on 'EM' quince (Cydonia oblonga Mill.) rootstock and grown in the experimental orchards at the Campus de Aula Dei, Zaragoza, Spain, were used for this work. The experiments were carried out using the same trees during 2 years, a first year (1998) and a second year (2000). Trees were selected for homogeneous size, bud load, and flowering habits and managed using standard procedures with irrigation during the full growing season. Trees were pruned in a vase-open-centered shape with three main axes. The cultivar Castell was used as the donor of compatible pollen (Sanzol and Herrero, 2002). Temperature conditions at flowering for both years were very similar, averaging $18.3{ }^{\circ} \mathrm{C}$ (maximum), $11.6^{\circ} \mathrm{C}$ (medium), and $4.9^{\circ} \mathrm{C}$ (minimum) for the first year and $17.7{ }^{\circ} \mathrm{C}$ (maximum), $11.4{ }^{\circ} \mathrm{C}$ (medium), and $5.1^{\circ} \mathrm{C}$ (minimum) for the second year.

Pollination Procedures. Self-pollen ('Agua de Aranjuez') and crosspollen ('Castell') were collected from flower buds at balloon stage at a time when the anthers were already mature but still undehisced. Anthers were removed and left to dry on a paper tray at room temperature. Pollen was sieved $48 \mathrm{~h}$ later with a $0.26-\mathrm{mm}$ mesh and stored at $4{ }^{\circ} \mathrm{C}$ until used. Pollen viability was assessed by evaluating in vivo pollen germination in a total of 15 stigmas. Overall, pollen germination was higher for 'Agua de Aranjuez' pollen than for 'Castell' pollen with percentages of $90 \%$ versus $68 \%$ and $85 \%$ versus $72 \%$ in the first and second years, respectively. Forty-eight hours before anthesis, 'Agua de Aranjuez' flowers were emasculated by removing the petals and anthers with the help of tweezers (Free, 1964), thus preventing flowers from the visits of pollinating insects. Hand-pollination was performed with a paint brush $48 \mathrm{~h}$ after emasculation. Flowers from branches not included in the experiment were left in the tree to maintain experimental conditions similar to standard growing conditions.
Microscopic ObServations. To monitor pollen tube growth in the style, flowers self-pollinated and crosspollinated at anthesis were sequentially collected, 15 flowers each day, during the first $6 \mathrm{~d}$ after pollination. For the observation of pollen tube penetration into the ovule, 15 flowers/fruitlets were collected $12 \mathrm{~d}$ after pollination. Pistils were fixed in (formalinacetic acid-ethanol 70\%) (1:1:18) (Johansen, 1940). After fixation, styles were washed three times, $1 \mathrm{~h}$ each wash, with distilled water and left overnight in 5\% sodium sulphite. The next day, they were autoclaved for $10 \mathrm{~min}$ at $1 \mathrm{~kg} \cdot \mathrm{cm}^{-2}$ (Jefferies and Belcher, 1974) and styles were mounted in squash preparations with $0.1 \% \mathrm{v} / \mathrm{v}$ aniline blue in $0.1 \mathrm{~N}$ $\mathrm{K}_{3} \mathrm{PO}_{4}$ (Linskens and Esser, 1957). For the observation of pollen tube penetration into the ovules, after fixation, ovaries from 12-d-old flowers were transversally split into two parts leaving the ovules in the lower half part of the ovary. They were washed twice with distilled water for $1 \mathrm{~h}$ each wash, then immersed in $4 \mathrm{~N} \mathrm{NaOH}$ for $1 \mathrm{~h}$ and washed again with distilled water until the ovules became dark brown or black. The ovules were then released from the ovary and mounted in squash with $0.1 \% \mathrm{v} / \mathrm{v}$ aniline blue in $0.1 \mathrm{~N} \mathrm{~K}_{3} \mathrm{PO}_{4}$ (Linskens and Esser, 1957). Preparations were viewed under an Ortholux II microscope (Leitz Co., Wetzlar, Germany) with ultraviolet epifluorescence using a BP 355-425 exciter filter and an LP 460 barrier filter.

Characterization of Early fruit development. To quantify early fruit development, pistils left unpollinated and crosspollinated at anthesis were collected daily (10 flowers/ fruitlets per day) during 3 weeks after anthesis and, after removing the sepals, they were weighted. Fertilization in set fruitlets was quantified to determine whether ovary development was induced as a response to fertilization and to estimate the proportion of fertilized ovules required to set a fruit. For this, the number of fertilized ovules was assessed in 3-week-old fruitlets with enlarged ovaries ( $9 \mathrm{~mm}$ long) by observing the ovules for the presence of pollen tubes penetrating the nucellus.

FrUIT DROP AND FRUIT SET EXPERIMENTS. Fruit set and fruit drop were recorded in self-pollinated, crosspollinated, and unpollinated flowers. To establish a population of flowers of the same age, branches with at least 30 flower clusters were randomly selected in three trees, one branch in each tree per treatment. In each cluster, the flowers at balloon stage were left (three flowers per cluster), whereas the opened and the delayed flowers were removed. After pollination, the number of flowers/ fruit was recorded weekly to monitor the pattern of flower/fruit drop. Initial fruit set was determined 4 weeks after pollination and final fruit set a few days before harvest.

Statistical Analysis. Differences in fruit set for crosspollinated, self-pollinated, and unpollinated flowers as well as differences in pollen tube performance for crosspollinated and self-pollinated flowers in both years of experiments were assessed by applying a test of comparison among proportions (Milton and Arnold, 2003). Data of, mean number of pollen tubes at the base of the style and number of seeds per fruit were subjected to analysis of variance and Duncan's multiple range tests using the StatGrafic software (Statistical Graphics Corp., Herndon, Va.).

\section{Results}

Characterization of pollen tube growth AND EARly Fruit DeVElopMent. Pollen tube performance after self- and 
crosspollination was examined in the first year of the experiment. Twenty-four hours after pollination, the emerging pollen tubes had already reached the transmitting tissue of the style (Fig. 1A, B). In crosspollinated flowers, the pollen tubes were observed growing throughout all the style length (Fig. 1C) and $5 \mathrm{~d}$ after pollination, they had already reached the base of the style (Fig. 2). At this time, however, self-pollen tubes had only reached $30 \%$ of the style length (Fig. 2), stopping its growth and exhibiting a characteristic SI reaction with swollen ends (Fig. 1D). Still, in some styles, some self-pollen tubes were observed reaching the base of the style. Thus, although $80 \%$ of the styles pollinated with crosspollen showed pollen tubes at their base, this only occurred in $8 \%$ of the styles of selfed flowers. In crosspollinated flowers, the pollen tubes reached the nucellus 8 to $11 \mathrm{~d}$ after pollination (Fig. 1E, F).

To establish the time of the onset of fruiting and to evaluate any natural tendency to parthenocarpy in this cultivar, crosspollinated and unpollinated pistils were weighed individually during the first 3 weeks after anthesis. Both populations (crossed and unpollinated pistils) behaved in a similar manner
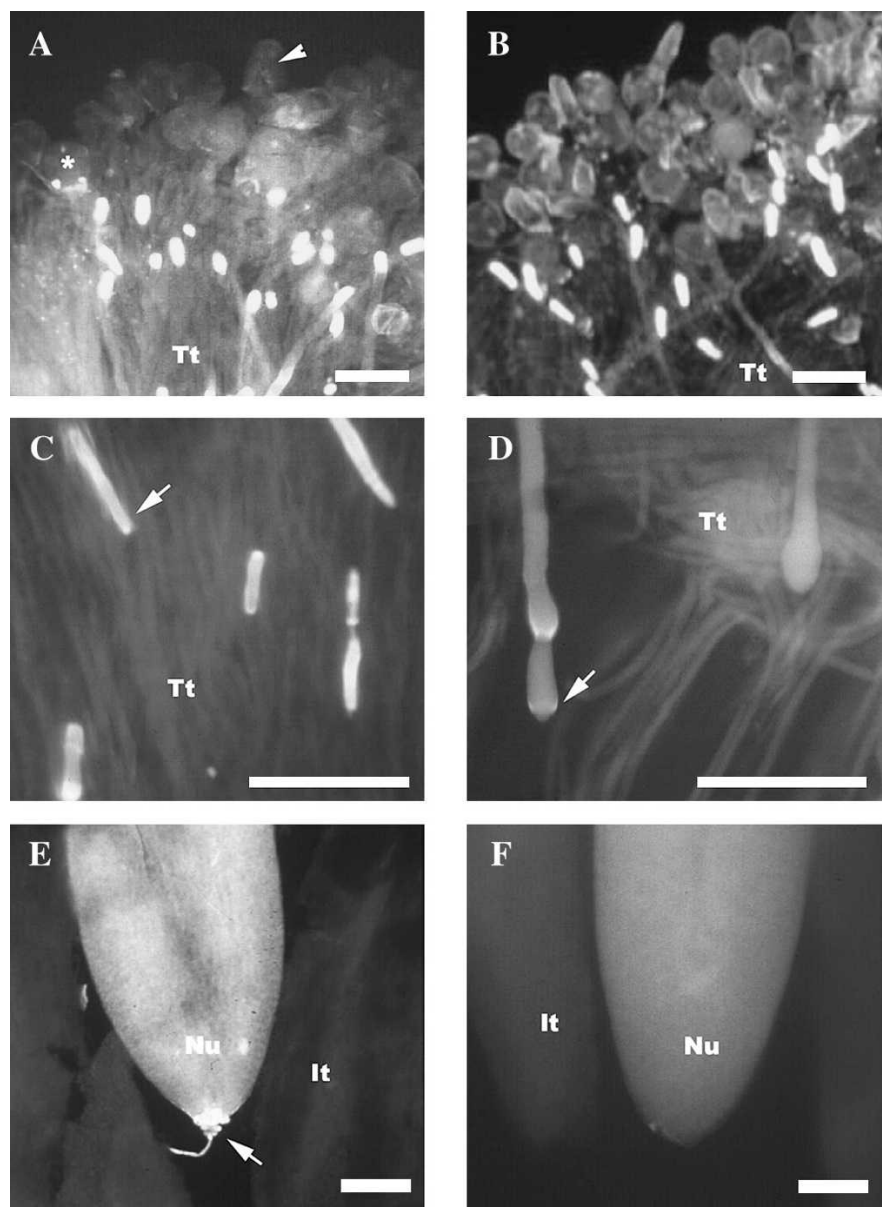

Fig. 1. Pollen tube growth after cross- and self-pollinations in 'Agua de Aranjuez' pear. (A) Pollen germination in a crosspollinated stigma $24 \mathrm{~h}$ after pollination; pollen grain $(*)$; stigmatic papilla (arrowhead). (B) Pollen germination in a self-pollinated stigma $24 \mathrm{~h}$ after pollination. (C) Pollen tubes growing in a crosspollinated style $5 \mathrm{~d}$ after pollination. Note pollen tubes showing callose plugs (arrow). (D) Pollen tubes in a self-pollinated style $5 \mathrm{~d}$ after pollination. Note pollen tubes showing swollen ends (arrow). (E) Ovule from a crosspollinated flower shows a pollen tube penetrating the nucellus (arrow). (F) Ovule from a self-pollinated flower. Fertilization is not observed. Bar = $100 \mu \mathrm{m} . \mathrm{Tt}=$ transmitting tissue; $\mathrm{Nu}=$ nucellus; $\mathrm{It}=$ integument. during the first days after anthesis without an apparent growth of the pistil in the first week of experiment (Fig. 3A, B). Between the ninth and 12th $\mathrm{d}$ after anthesis, an increase in ovary size was observed in the majority of crosspollinated pistils, whereas the unpollinated pistils did not show any sign of growth (Fig. 3A, B). Thus, two groups of crosspollinated pistils were established - one with growing ovaries, which constituted the initial fruit set, and a second one that did not grow and dropped during the third and fourth week after anthesis.

The role of fertilization in the onset of fruit development was evaluated by quantifying the proportion of fertilized ovules in set fruitlets. From the 10 ovules present in the flower, the number of fertilized ovules per flower ranged from one to eight with the average number being 3.7 fertilized ovules per flower (standard deviation $=2.4$ ). Moreover, in all the enlarged fruitlets sampled, at least one ovule per flower was fertilized.

FLOWER/FRUIT DROP AFTER CROSS- AND SELF-POLLINATION. Flower/fruit drop for flowers under the treatments of crosspollination, self-pollination, and unpollination was studied in the 2 years of the study. The pattern of drop for both years is shown in Figures $4 \mathrm{~A}$ and B. Figures $4 \mathrm{C}$ and D summarize the results from the statistical analysis for the comparison of initial and final fruit set values between years and between treatments. Although for both years, fruit drop curves followed a similar pattern (Fig. 4A, B), significant differences were recorded for initial and final fruit set between years both for crosspollinated and self-pollinated flowers (Fig. 4C, D). However, differences between years were not significant for unpollinated flowers (Fig. 4C, D). Between-treatment comparison showed that both initial and final fruit set were significantly higher after crosspollination than after self-pollination or unpollination for both years (Fig. 4C, D). Similarly, the comparison of fruit set between self-pollinated and unpollinated flowers resulted in significantly higher initial fruit set for self-pollinated than for unpollinated flowers also in both years. For final fruit set values, however, although self-pollinated flowers did not show significantly higher records than unpollinated flowers in the first year (Fig. 4C), differences between both treatments were significant in the second year (Fig. 4D).

Pollen tube BeHAVIOR AFTER CROSS- AND SELF-POLLINATION. In an attempt to understand the differences recorded in fruit set between years, pollen tube performance was compared for the 2 years of the study. For pollen tube performance in the style (Fig. 5), significant differences between crosspollinated and

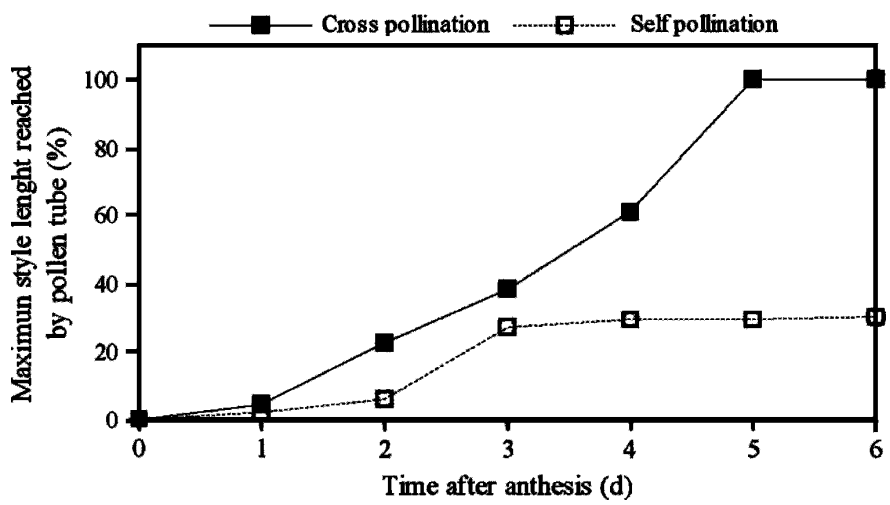

Fig. 2. Kinetics of pollen tube growth in the style of 'Agua de Aranjuez' pear in cross- (ם) and self-pollinated ( $\square$ ) flowers expressed as the maximum percentage of style length reached by the pollen tube. Data corresponding to the first year. 

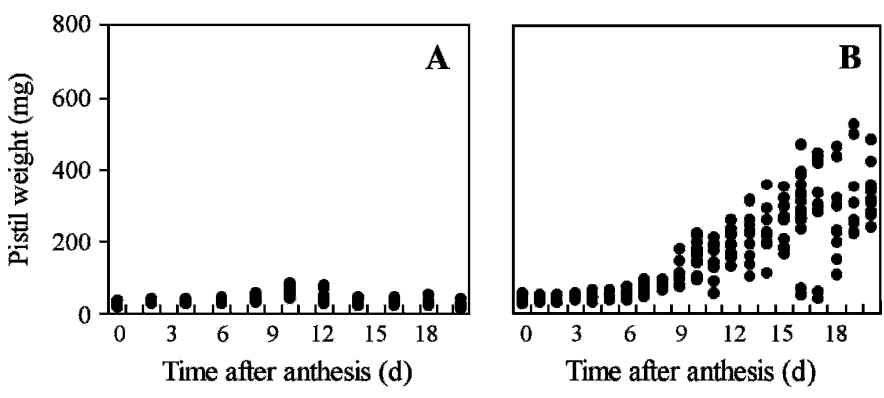

Fig. 3. Pistil weight of unpollinated (A) and crosspollinated (B) 'Agua de Aranjuez' pear flowers during $20 \mathrm{~d}$ after anthesis. Data corresponding to the first year.

self-pollinated flowers were observed in both years regarding the proportion of styles (Fig. 5A) or flowers with styles (Fig. $5 \mathrm{~B})$ with pollen tubes in the base of the style. Also, there were significant differences in terms of the mean number of pollen tubes that reached the base of the style (Fig. 5C) with values of 1.2 and 4.2 pollen tubes in self-pollinated and crosspollinated flowers, respectively. The comparison between years showed that the percentage of styles with pollen tubes in the base of the style was slightly higher for the second year both in crosspollinated and self-pollinated flowers (Fig. 5A), although these differences were only statistically significant for crosspollinated flowers. Differences between years were statistically significant when pollen tube penetration into the ovule was observed. In self-pollinated flowers, although no fertilized ovules were recorded in the first year, the percentage of fertilized ovules was $8 \%$ in the second year (Fig. 5D).
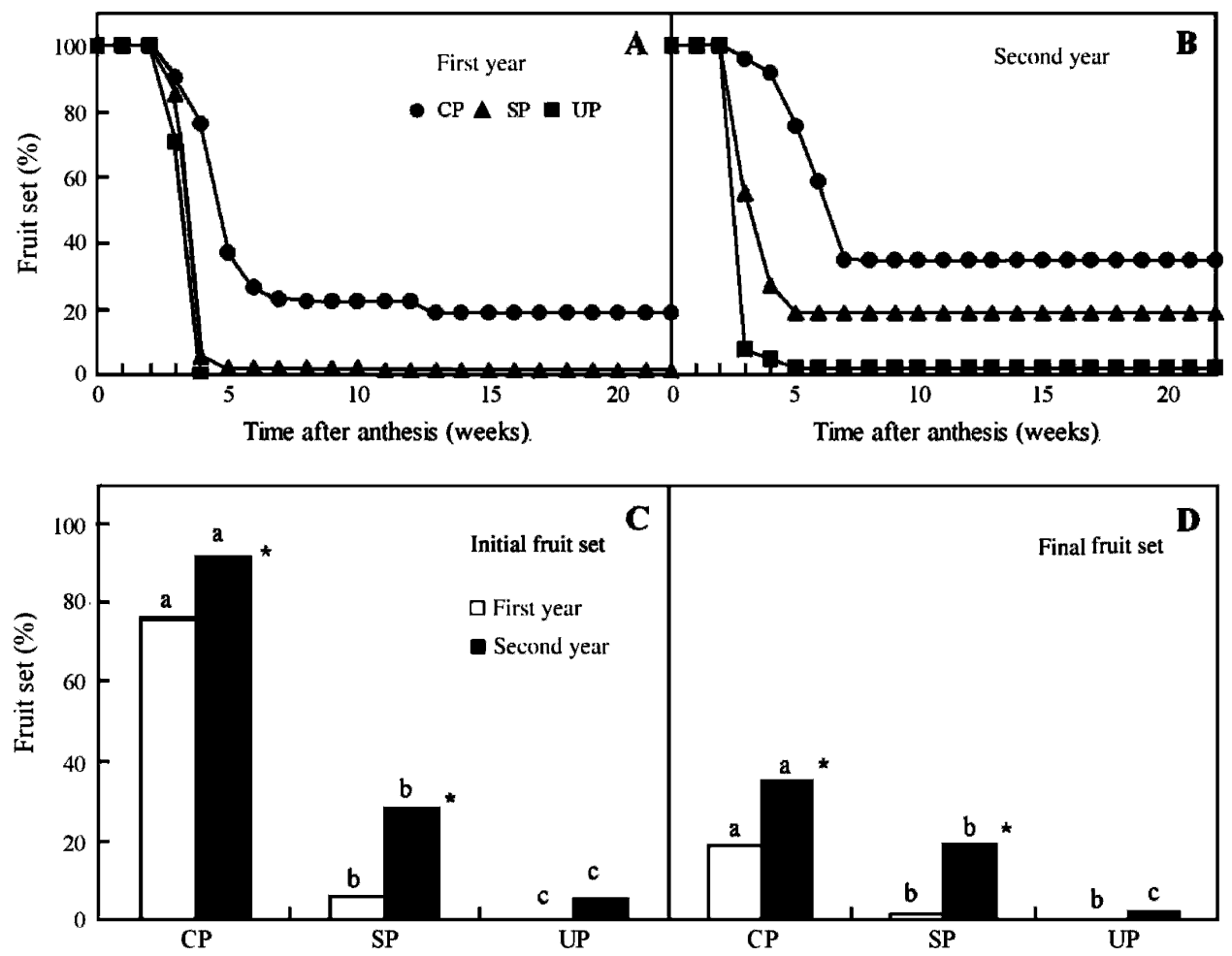

Fig. 4. Flower and fruit drop in 'Agua de Aranjuez' pear for unpollinated (UP), crosspollinated (CP), and selfpollinated (SP) flowers in the first (A) and second (B) year. Flower/fruit set data were recorded for 22 weeks from anthesis. (C) Initial and (D) final fruit set comparisons for crosspollinated, self-pollinated, and unpollinated flowers in the 2 years. Treatments with the same letter for the same year are not different $(P \leq 0.01)$. *Significant differences between years $(P \leq 0.01)$.
Moreover, when data were expressed as percentage of flowers with at least one fertilized ovule, this value was $0 \%$ in the first year but reached $30 \%$ in the second year (Fig. 5E), a value close to initial fruit set for this year (27\%; Fig. 4). Altogether, pollen tube performance results are consistent with the records of seed number per fruit obtained (Fig. 5F). Thus, seed set was significantly higher in the second year for both crosspollinated and self-pollinated flowers. Moreover, only in the second year, seeded fruit resulting from self-pollinated flowers were harvested (Fig. 5F).

\section{Discussion}

Slight differences in self-pollen tube performance may result in clear differences in fruit set. Results here show that although 'Agua de Aranjuez' pear behaves as SI and does not show a clear parthenocarpy, a low level of selfing can account for a moderate fruit set. Given that flowers with only one fertilized ovule are able to set fruit, our conclusion is supported by the observation that initial fruit set recorded for self-pollinated flowers can be explained by a similar proportion of selffertilized flowers. Initial fruit set is the result of a response to fertilization. This conclusion has been supported by two independent observations: 1) the onset of ovary growth occurs only in crosspollinated flowers and after fertilization, but not in unpollinated flowers; and 2) 3-week-old set fruitlets present at least one fertilized ovule.

'Agua de Aranjuez' pear behaves as SI. This is evident in terms of quantitative data and morphologic observations regarding pollen tube performance. In selfed flowers, most pollen tubes are arrested along the first third of the style, the place where the incompatibility response has been shown to take place in the pear (Lewis and Modlibowska, 1942; Marcucci and Visser, 1987; Modlibowska, 1945). However, although this blockage in pollen tube growth is consistently observed, some self-pollen tubes do not stop at this region and they continue growing to reach the stylar base. This behavior has been observed in a similar proportion to the values that have reported for other pear cultivars (Lombard et al., 1972; Vasilakakis and Porlingis, 1985). In both years also, after self-pollination, we have observed pollen tubes growing inside the ovary locule and eventually reaching the region close to the ovule exostome. However, fertilized ovules were observed under selfpollination only in the second year of the study. The question remains about what could have determined this differential behavior between years in the performance of selfpollen tubes. Temperature during the reproductive process has been shown to have an effect on the rate 


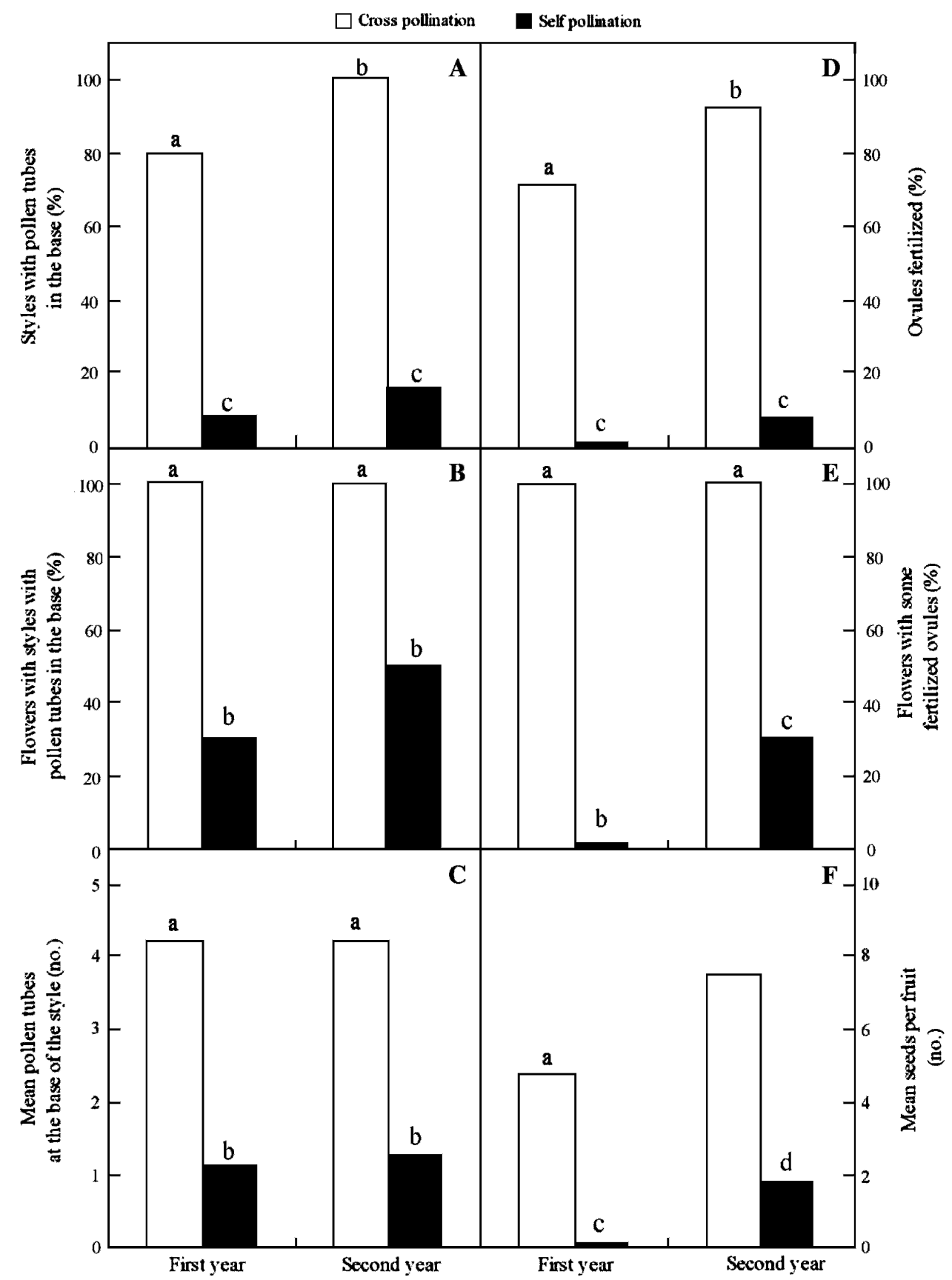

Fig. 5. Pollen tube performance in the style, pollen tube performance in the ovary, and seed records for crosspollinated (open bars) and self-pollinated (solid bars) 'Agua de Aranjuez' pear flowers in the 2 years. (A) Percentage of styles with pollen tubes at the base of the style, (B) percentage of flowers with at least one style with pollen tubes at the base, $(\mathbf{C})$ mean number of pollen tubes at the base of the style, (D) percentage of ovules fertilized, (E) flowers with at least one fertilized ovule, and (F) mean number of seeds per fruit. Different letters for a treatment denote significant differences $(P \leq 0.01)$. All the comparisons between self- and crosspollinated flowers are significant. Number of seeds per fruit, mean separation by Duncan's multiple range test $(P \leq 0.01)$.

fertility has been also observed in the self-fruitful year for flowers under crosspollination. Flower fertility has been shown to be susceptible to manipulation through adequate agricultural practices (reviewed in Sanzol and Herrero, 2001). As a consequence, orchard management can have an especial relevance optimizing yields when fruit set is obtained under selfpollination in pear.

Differences in the level of rejection of self-pollen have been also reported in other species closely related to pear. Schneider et al. (2001) have studied the SI of 'Golden Delicious', an apple cultivar that has been considered to be self-compatible. Their experiments have shown the self-fertilization potency of this apple cultivar by implementing a polymerase chain reaction-S-allele analysis. Also, recent work by Hiratsuka and Zhang (2002) has addressed the differential expression of the SI among japanese pear cultivars by analyzing S-RNase protein concentration at the style. Their results suggest that cultivar differences in the response to selfpollination are at least partially explained by differences in the expression of the S-RNase protein. In pear, Lewis and Modlibowska (1942) studied the origin of the pollen tubes that break the incompatibility barrier under selfpollination in the cultivar fertility and observed that most of the seeds obtained by selfing were triploid. In agreement with the self-compatibility behavior of tetraploid genotypes, Crane and Lewis (1942) and Lewis and Modlibowska, (1942) raised the hypothesis that selfing in pear is the result of the self-compatible behavior of unreduced pollen during meiosis bearing two different selfhaplotypes. The recent identification of S-RNase allelic sequences in pear (Zisovich et al., 2004; Zuccherelli et al., 2002) is acceler-

of pollen tube growth (Hedhly et al., 2004; reviewed in Sanzol and Herrero, 2001). However, a comparison of daily mean temperatures in the period between pollination and fertilization shows little differences between both years (see "Materials and Methods"), making it unlikely that the temperature could have a major role in the different fertilization response observed between years. Alternatively, this differential behavior could be the result of differences between years in the fertility of the flowers. This argument is favored by the fact that a higher ating the characterization of S-genotypes in this species and the identification of new cross-incompatibilities. With this information, the evaluation of the incompatibility reaction not only in self-pollinations, but in cross-incompatible combinations will shed light on these hypotheses.

Similar to 'Agua de Aranjuez' pear, self-incompatibility and self-fruitfulness for other pear cultivars has been reported to be a controversial subject (Callan and Lombard, 1978; Cambra, 1962; Griggs and Iwakiri, 1954; Sotes, 1975; Vasilakakis and 
Porlingis, 1985). Contradictory results have mainly arisen because some cultivars have been characterized by variable results on fruit set when it has been determined under controlled self-pollination or under free pollination with trees planted in solid blocks. This behavior has been partially explained by the parthenocarpy of some pear cultivars, which is widely exploited in pear production. However, not all the pear cultivars are characterized by a parthenocarpic response and fertilization is required to set fruit in many of them (Moriya et al., 2005; Nyeki, 1974; Nyeki et al., 1998). Results here show that selffertilization, although occurring at a low level, can explain moderate fruit set considering that fruiting occurred in flowers with only one fertilized ovule. No information exists as to what extent this behavior can be generalized to other pear cultivars. However, given that a variable response to selfing has been reported for a good range of pears and that cultivars bearing single-seeded fruit are common (Nyeki, 1977), the behavior observed for 'Agua de Aranjuez' could be widespread in Pyrus communis. This could explain inconsistent reports about selffruitfulness in other pear cultivars.

\section{Literature Cited}

Broothaerts, W., G.A. Janssens, P. Proost, and W.F. Broekaert. 1995. cDNA cloning and molecular analysis of two self-incompatibility alleles from apple. Plant Mol. Biol. 27:499-511.

Callan, N.W. and P.B. Lombard. 1978. Pollination effects on fruit and seed development in 'Comice' pear. J. Amer. Soc. Hort. Sci. 103:496-500.

Cambra, M. 1962. Determinación de variedades polinizadoras del peral 'Agua de Aranjuez'. Anales de Aula Dei 7:85-92.

Christine, J., J. Gorter, and T. Visser. 1956. Parthenocarpy of pears and apples. J. Hort. Sci. 33:217-227.

Crane, M.B. and D. Lewis. 1942. Genetical studies in pears III. Incompatibility and sterility. J. Genet. 43:31-44.

de Nettancourt, D. 2001. Incompatibility and incongruity in wild and cultivated plants. Springer, Berlin, Germany.

Free, J.B. 1964. Comparison of the importance of insect and wind pollination of apple trees. Nature 201:726-727.

Griggs, W.H. and B.T. Iwakiri. 1954. Pollination and parthenocarpy in the production of 'Barlett' pears in California. Hilgardia 22:643-678. Hedhly, A., J.I. Hormaza, and M. Herrero. 2004. Effect of temperature on pollen tube kinetics and dynamics in sweet cherry, Prunus avium (Rosaceae). Amer. J. Bot. 91:558-564.

Hiratsuka, S. and S.L. Zhang. 2002. Relationships between fruit set, pollen-tube growth, and S-RNase concentration in the self-incompatible japanese pear. Scientia Hort. 95:309-318.

Ishimizu, T., K. Inoue, M. Shimonaka, T. Saito, O. Terai, and S. Norioka. 1999. PCR-based method for identifying the S-genotypes of japanese pear cultivars. Theor. Appl. Genet. 98:961-967.

Jaumien, F. 1968. The cause of poor bearing trees of the variety Doyenne du Comice. Acta Agrobotanica 21:75-106.

Jefferies, C.J. and A.R. Belcher. 1974. A fluorescent brightener used for pollen tube identification in vivo. Stain Technol. 49:199-202.

Johansen, D.A. 1940. Plant microtechnique. McGraw-Hill, N.Y.

Lewis, D. and I. Modlibowska. 1942. Genetical studies in pears IV. Pollen-tube growth and incompatibility. J. Genet. 43:211-222.

Linskens, H.F. and K. Esser. 1957. Über eine spezifische Anfärbung der Pollenschläuche im Griffel und die Zahl der Kallosepfropfen nach Selbstdung und Fremddung. Naturwissenschaften 44:1-2.

Lombard, P.B., R.R. Williams, K.G. Stott, and C.J. Jeffries. 1972. Temperature effects on pollen tube growth in styles of 'Williams' pear with a note on pollination deficiencies of Comice pear. Compte rendue du symposium 'Culture du Poirier'. p. 265-279.

Marcucci, M.V. and T. Visser. 1987. Pollen tube growth in apple and. pear styles in relation to self-incompatibility, incongruity and pollen load. Adv. Hort. Sci. 1:90-94.
Milton, J.S. and J.C. Arnold. 2003. Introduction to probability and statistics: Principles and applications for engineering and the computing sciences. McGraw-Hill, Mexico D.F., Mexico.

Modlibowska, I. 1945. Pollen tube growth and embryo-sac development in apples and pears. J. Pomol. 21:57-89.

Moriya, Y., Y. Takai, K. Okada, D. Ito, Y. Shiozaki, T. Nakanishi, and T. Takasaki. 2005. Parthenocarpy and self- and cross-incompatibility in ten European pear cultivars. J. Jpn. Soc. Hort. Sci. 74:424-430.

Nyeki, J. 1974. Natural parthenocarpy in pear varieties. Acta Agrobotanica Academiae Scientiarum Hungaricae 26:282-289.

Nyeki, J. 1977. Fructification and number of seeds per fruit in pear varieties. Acta Agrobotanica Academiae Scientiarum Hungaricae 26:282-289.

Nyeki, J., M. Soltesz, and J. Ivancsics. 1998. Natural tendency to partenocarpy of pear varieties in Hungary. Acta Hort. 475:367-377.

Sanzol, J. 2001. Mecanismos reproductivos que regulan la fructificación en peral (Pyrus communis L.) cv. Agua de Aranjuez. Universidad Pública de Navarra, Pamplona, Spain, $\mathrm{PhD}$ thesis.

Sanzol, J. and M. Herrero. 2001. The effective pollination period in fruit trees. Scientia Hort. 90:1-17.

Sanzol, J. and M. Herrero. 2002. Identification of self-incompatibility alleles in pear cultivars (Pyrus communis L.). Euphytica 128:325-331.

Schneider, D., R.A. Stern, D. Eisikowitch, and M. Goldway. 2001. Determination of the self-fertilization potency of 'Golden Delicious' apple. J. Hort. Sci. Biotechnol. 76:259-263.

Sotes, V. 1975. Estudio del crecimiento del tubo polínico y de la longevidad de óvulos en la variedad de peral 'Blanquilla de Aranjuez'. Investigación Técnica Económica Agraria 19:23-29.

Stern, R.A., M. Goldway, A.H. Zisovich, S. Shafir, and A. Dag. 2004. Sequential introduction of honeybee colonies increases crosspollination, fruit-set and yield of 'Spadona' pear (Pyrus communis L.). J. Hort. Sci. Biotechnol. 79:652-658.

Takasaki, T., Y. Moriya, K. Okada, K. Yamamoto, H. Iwanami, H. Bessho, and T. Nakanishi. 2006. cDNA cloning of nine $\mathrm{S}$ alleles and establishment of a PCR-RFLP system for genotyping European pear cultivars. Theor. Appl. Genet. 112:1543-1552.

Tassinari, P., S. Zuccherelli, and S. Sansavini. 2001. Contributo allo studio delle basi biologico-molecolari dell'incompatibilità gametofitica del pero (Pyrus communis L.). Rivista di Frutticoltura e di Ortoflorocultura 6:81-86.

Tassinari, P., S. Zuccherelli, and S. Sansavini. 2004. Self-pollination and fertility in european pear (Pyrus communis L.) cultivars. Acta Hort. 663:677-680.

Ushijima, K., H. Sassa, A.M. Dandekar, T.M. Gradziel, R. Tao, and H. Hirano. 2003. Structural and transcriptional analysis of the selfincompatibility locus of almond: Identification of a pollenexpressed F-box gene with haplotype-specific polymorphism. Plant Cell 15:771-781.

Vasilakakis, M.D. and I.C. Porlingis. 1985. Effect of temperature on pollen germination, pollen tube growth, effective pollination period, and fruit set of pear. HortScience 20:733-735.

Waite, M.B. 1894. The pollination of pear flowers. U.S. Dept. Agr. Div. Veg. Path. Bul. 5.

Williams, R.R. and M. Maier. 1977. Pseudo-compatibility after selfpollination of the apple 'Cox's Orange Pippin'. J. Hort. Sci. 55:475-483.

Zhang, S.L. and S. Hiratsuka. 2000. Cultivar and developmental differences in S-protein concentration and self-incompatibility in the japanese pear. HortScience 35:917-920.

Zhang, S.L. and S. Hiratsuka. 2005. Analyses of pollen-tube growth and biological action of S-RNase in the style of self-compatible japanese pear. Scientia Hort. 104:169-178.

Zisovich, A.H., R.A. Stern, S. Shafir, and M. Goldway. 2004. Identification of S-alleles from the european pear (Pyrus communis L.) and the determination of compatibility among cultivars. J. Hort. Sci. Biotechnol. 79:101-106.

Zuccherelli, S., P. Tassinari, W. Broothaerts, S. Tartarini, L. Dondini, and S. Sansavini. 2002. S-allele characterization in self-incompatible pear (Pyrus communis L.). Sex. Plant Reprod. 15:153-158. 